\title{
WACANA KENABIAN SETELAH NABI MUHAMMAD SAW
}

Oleh:

\section{Armyn Hasibuan ${ }^{1}$}

\begin{abstract}
Patient behavior is behavior that Allah commanded and selection of attitude to be auspicious. Forms can be patience in obedience to Allah, to be patient in accepting the trials of life, patient of encouragement passion of lust, invite the people to be patient in the way of Allah, to be patient in conditions of war, and to be patient in social life. The primacy of the patient, among other things for him Paradise, Allah will love him, his sins will be deleted to be canged and he may reward. Patient has relationship with mental coaching, among others: patience as mental therapy, patient as an indicator of the creation of mental health, and thereis patient as a means of developing a healthy self mentally.
\end{abstract}

Keywords: Patient behavior, mental therapy, and mental health

\footnotetext{
${ }^{1}$ Penulis adalah Dosen Fakultas Dakwah dan ilmu Komunikasi IAIN Padangsidimpuan
} 


\section{Pendahuluan}

Seorang Nabi belum tentu rasul tetapi seorang rasul sudah pasti dia juga seorang nabi. Nabi maupun rasul sama sama memberi penjelasan bagi umat manusia agar manusia senantiasa berada di jalan kebenaran seperti jalan ketuhanan. Nabi seorang manusia terkemuka yang berkemampuan memberi berita eskatologi dan hal hal yang lain. Menurut T.M. Hasbi Ash Shiddiqi sebagai dikutip oleh Muhammad Daud Ali bahwa nabi yang pernah memimpin manusia ada 124.000 orang dan rasul sebanyak 313 orang, hanya 25 orang saja yang dimaktubkan oleh Allah Swt. dalam Alquran. ${ }^{2}$

Perbedaan yang mendasar antara nabi dan rasul adalah TUPOKSI ( Tugas Pokok dan Fungsi) nya, dimana para nabi tidak mempunyai kewajiban menyampaikan berupa ilham yang diperolehnya kepada umat manusia, sedangkan para rasul berkewajiban menyampaikan wahyu yang diterimanya kepada umat manusia.

Nabi Muhammad SAW. disebutkan dalam Alquran sebagai nabi terakhir dan dikuatkannya dengan hadits beliau yang kira kira artinya: “... Tidak ada nabi sesudahku ...".meskipun di masa itu tetap saja ada orang yang mendeklarasikan dirinya sebagai nabi, seperti Musailamah al Kazzab. Demikian juga di masa setelah nabi Muhammad Saw. Seperti di Indonesia sendiri ada beberapa orang yang mengaku nabi di tengah masyarakat antara lain Abdul Muhjib, Eyang Ended, Lia Eden dan Ahmad Musaddeq. ${ }^{3}$

Wacana kenabian menjadi diskursus atau perbincangan utamanya pada beberapa aliran dalam islam seperti dalam sekte Syiah yang mengkaitkannya dengan politik imamah dan Ahmadiah Qodianiyah mereka terus mengkajinya, membicarakannya dan meyakini bahwa ada lagi nabi setelah Muhammad Saw. Ahmadiyah Qodianiyah sebagai satu aliran menganggap, menyakini dan mengakui Mirza Ghulam Ahmad sebagai nabi yaitu Isa Al-masih dan Imam Mahdi. ${ }^{4}$

Umat islam pada umumnya dan khususnya jumhur ulama berkeyakinan secara mutawattir bahwa kenabian setelah nabi Muhammad saw telah final yakni tidak ada lagi nabi sesudahnya. Hal ini dipahami dari Alquran surah al- Ahzab: 40

\footnotetext{
${ }^{2}$ Mohammad Daud Ali, Pendidikan Agama Islam (Jakarta: Raja Grafindo Persada,1998), hlm. 222 .

${ }^{3}$ Iyakan.Com, Diakses pada Hari Rabu tgl. 12 Desember 2018, Pukul 08.45

${ }^{4}$ Ihsan Ilahi Dzakir, Ahmadiyah Qadiyahmiah, Sebuah Kajian Analisis, Terjemah Harapaudi Dahri ( Jakarta: BPPA, 2008). Hlm. 8.
} 


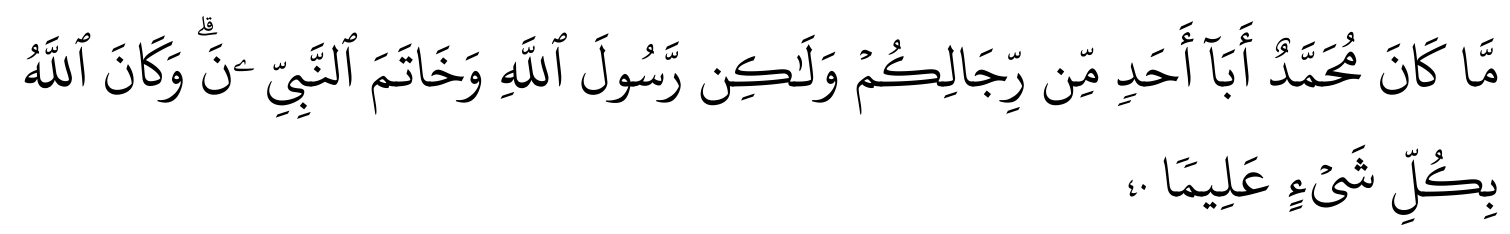

Artinya: Muhammad itu sekali-kali bukanlah bapak dari seorang laki-laki di antara kamu. Tetapi Dia adalah Rasulullah dan penutup nabi-nabi. dan adalah Allah Maha mengetahui segala sesuatu. ${ }^{5}$

لا نبي من Hadits nabi Muhammad saw, yang secara eksplisitpun menjelaskan ... بعدي "tidak ada nabi sesudahku", hanya saja kenabian yang dipahamkan dari kata khatam al nabiyyin di pandang memakai kata atau isim musytarok yakni memikliki makna ganda, kata khatam bukan diartikan penutup saja tetapi bisa juga artinya cap, stempel, segel, lak dan cincin $^{6}$, sehingga hal itulah yang menjadi celah pintu masuk untuk mengkaji bahkan mentaukidkan adanya lagi nabi setelah Muhammad SAW. Tentu hal ini sesuatu yang signifikan dikaji dan didiskusikan sebagai suatu wacana.

Demikian juga penafsiran Q.S. al Nisa ayat 164 yang berbunyi:

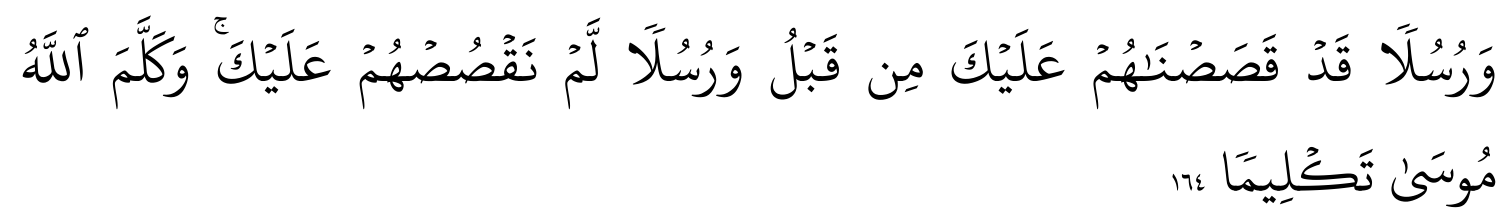

Artinya: dan (Kami telah mengutus) Rasul-rasul yang sungguh telah Kami kisahkan tentang mereka kepadamu dahulu, dan Rasul-rasul yang tidak Kami kisahkan tentang mereka kepadamu. dan Allah telah berbicara kepada Musa dengan langsung ${ }^{7}$

${ }^{5}$ Depag. RI. Al Quran dan Terjemahnya, (Semarang: Toha Putra 1998), hlm. 674.

${ }^{6}$ Ahmad Warson Munawwir,Al Munawwir Kamus Arab-Indonesia (Yogyakarta: Pustaka Progressif, t.t.), hlm. 348.

${ }^{7}$ Op.Cit., hlm. 151. 
Dan juga di dalam Q.S.al-Mukmin ayat 78 yang berbunyi:

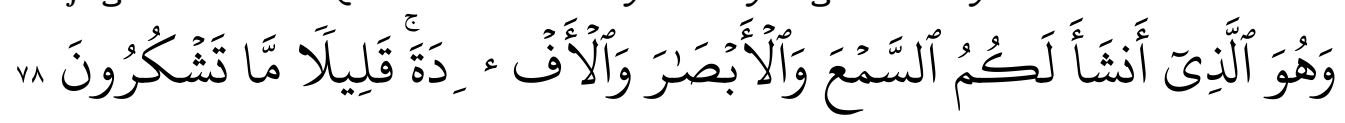

Artinya: dan Sesungguhnya telah Kami utus beberapa orang Rasul sebelum kamu, di antara mereka ada yang Kami ceritakan kepadamu dan di antara mereka ada (pula) yang tidak Kami ceritakan kepadamu... ${ }^{8}$

Keduanya ditafsirkan secara parsial dan menangkap makna yang tidak didasari dengan ilmu bahasa dan tafsir yang sebenarnya dengan mengambil kesimpulan bahwa ada rasul yang tidak diceritakan dalam Alquran, hal ini melihat kata yang digunakan fiil mudhari' berarti kejadiannya bisa di masa sekarang dan masa mendatang tanpa melihat susunan dan fungsi kalimat.

Ada juga yang ingin mencari popularitas nama dengan nekat mengaku diri sebagai seorang nabi, Syiah mengkaitkannya dengan politik imamah bahwa Tuhan tidak membiarkan suatu umat dalam kurun waktu kurang lebih 100 tahun tanpa seorang mujaddid (pembaharu) atau imam sebagai perpanjangan tangan Tuhan untuk mengatur dan membawa manusia ke jalan yang benar seperti jalan ketuhanan. Kata mujaddid ( pembaharu) bisa seorang nabi,wali atau imam meskipun tidak sehebat Muhammad SAW. karena beliau sayyid anbiya wa al Mursalin berarti penghulu sekalian nabi dan rasul alias pemungkas. Hal ini juga membuat sebagian menanti kedatangan nabi yang bisa berubah nama seperti penyelamat atau imam.

Dalam makalah ini, penulis akan menyajikannya dengan pendekaatan hadits-hadits tematik meskipun masih memakai beberapa ayat sebagai landasan dasar dan mengkorelasikannya dengan asbabu al Wurud, kesejarahan dengan analisa filsafat sebagai hasil diskusi mahasiswa Strata Tiga Akidah Filsafat Islam SM.1 T.A.2018/2019

\section{Pengertian dan Landasan Pikir}

Wacana kenabian adalah diskursus atau juga perbincangan tentang nabi, apakah masih ada seusai nabi Muhammad SAW. atau tidak ada lagi, dengan mengutarakan berbagai hadits secara eksplisit maupun implisit. Dasar pikir pendekatan tentang wacana kenabian antara lain:

a. QS. Al ahzab:40 Allah swt berfirman:

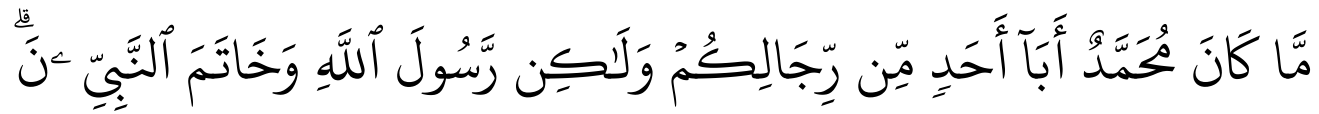

Artinya: Muhammad itu sekali-kali bukanlah bapak dari seorang laki-laki di antara kamu tetapi Dia adalah Rasulullah dan penutup nabi-nabi?

${ }^{8}$ Ibid., hlm.770. 
b. Adanya pemahaman yang tidak komprehensif tentang:

Q.S. al-A'raaf: 35

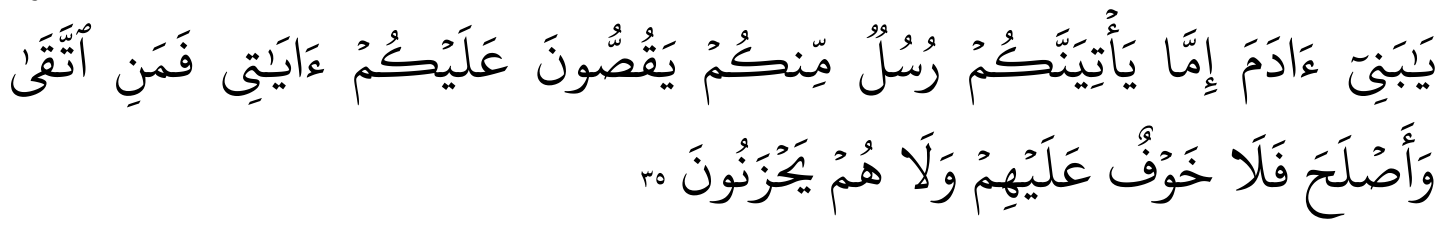

Artinya: Hai anak-anak Adam, jika datang kepadamu Rasul-rasul daripada kamu yang menceritakan kepadamu ayat-ayat-Ku, Maka Barangsiapa yang bertakwa dan Mengadakan perbaikan, tidaklah ada kekhawatiran terhadap mereka dan tidak (pula) mereka bersedih hati. ${ }^{10}$

Q.S. al Nisa: 164

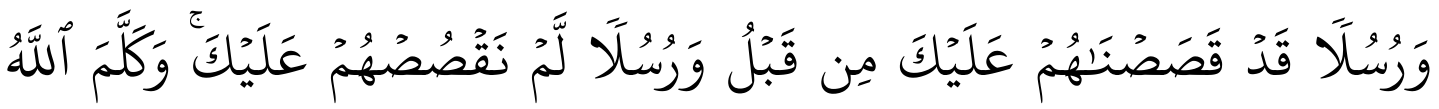

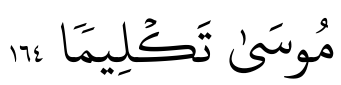

Artinya: Dan (kami telah mengutus) Rasul-rasul yang sungguh telah Kami kisahkan tentang mereka kepadamu dahulu, dan Rasul-rasul yang tidak Kami kisahkan tentang mereka kepadamu. dan Allah telah berbicara kepada Musa dengan langsung

Q.S.al Mukmin: 78

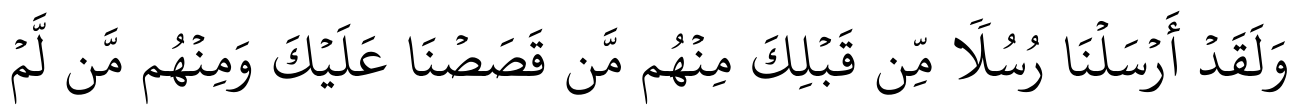

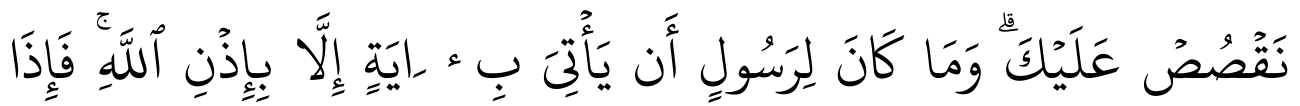

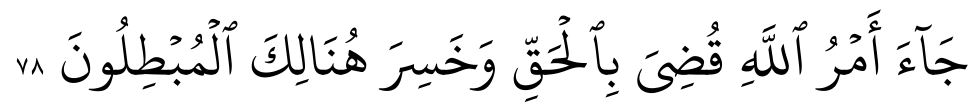

Artinya: Dan Sesungguhnya telah Kami utus beberapa orang Rasul sebelum kamu, di antara mereka ada yang Kami ceritakan kepadamu dan di antara mereka ada (pula) yang tidak Kami ceritakan kepadamu. tidak dapat bagi seorang Rasul membawa suatu mukjizat, melainkan dengan seizin Allah; Maka apabila telah datang perintah

\footnotetext{
${ }^{9}$ Ibid., hlm.

${ }^{10}$ Ibid., hlm. 226.
} 
Allah, diputuskan (semua perkara) dengan adil. dan ketika itu rugilah orang-orang yang berpegang kepada yang batil. ${ }^{11}$

Q.S. al Anbiya : 107

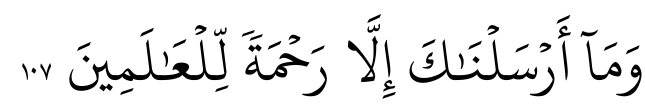

Artinya: Dan Tiadalah Kami mengutus kamu, melainkan untuk (menjadi) rahmat bagi semesta alam.

c. Adanya pemahaman bahwa di dalam masa 100 tahun, Allah SWT. akan memunculkan seorang mujaddid, pembaharu dalam pemahaman agama. Pembaharu itu menjadi wacana pembicaraan, sebagian orang mengatakan, dia itu seorang nabi, seorang pemberita eskatologi yang memiliki kemampuan pikir, kecerdasan, kebijakan dan lainnya sehingga orang banyaklah yang menyatakannya sebagai nabi (pemberi kabar), imam atau ikutan.

d. Adanya hadits yang matannya bermuatan kenabian yaitu:

$$
\text { كيف انتم اذا نزل فيكمابن مر يم وامامكم منكم }
$$

Artinya: “ .... Bagaimana sikap kalian apabila telah turun ibnu Maryam pada kalangan kalian, sedangkan dia menjadi imam dari antara kalian.... ${ }^{12}$

e. Ingkar sunnah, dengan terkontaminasi filsafat sekuler.

Pemahaman bahwa kenabian, apakah berada pada ranah taaqquliah atau ghaira taaqquliah. Ada golongan yang menolak hadits (utamanya hadits ahad) sebagai hujjah termasuk Qadariyah Rafidhah dan sebagian mazhab al Zahiry.

\section{Pembahasan}

\section{Wacana Bagi yang Menolak Adanya Nabi Setelah Muhammad SAW.}

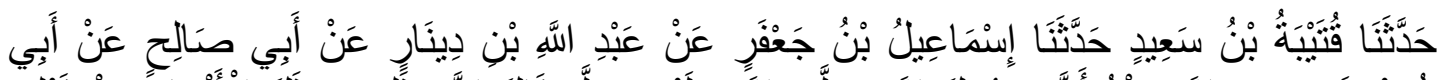

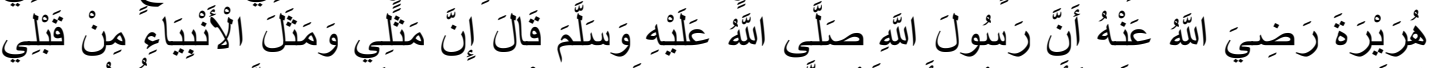

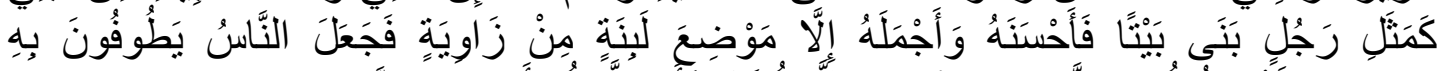

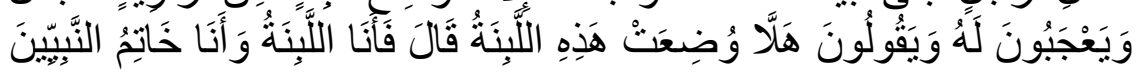

${ }^{11}$ Ibid., hlm.770.

${ }^{12} \mathrm{Abu}$ Abdillah Muammad Bin Ismail Al-Bukhari, Shahih Bukhari, cet.1 (Beirut: Dari Ibn Katsir, 2002), hlm. 855. 
Artinya: Telah bercerita kepada kami Qutaibah bin Sa'id telah bercerita kepada kami Isma'il bin Ja'far dari 'Abdullah bin Dinar dari Abu Shalih dari Abu Hurairah radliallahu 'anhu bahwa Rasulullah shallallahu 'alaihi wasallam bersabda: "Perumpamaanku dan nabinabi sebelumku seperti seseorang yang membangun suatu rumah lalu dia membaguskannya dan memperindahnya kecuali ada satu labinah (tempat lubang batu bata yang tertinggal belum diselesaikan) yang berada di dinding samping rumah tersebut, lalu manusia mengelilinginya dan mereka terkagum-kagum sambil berkata; 'Duh seandainya ada orang yang meletakkan labinah (batu bata) di tempatnya ini". Beliau bersabda: "Maka akulah labinah itu dan aku adalah penutup para nabi". ( H.R. Bukhori. No. 3271). ${ }^{13}$

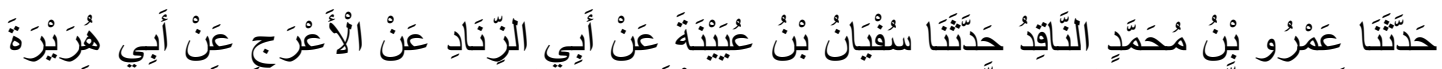

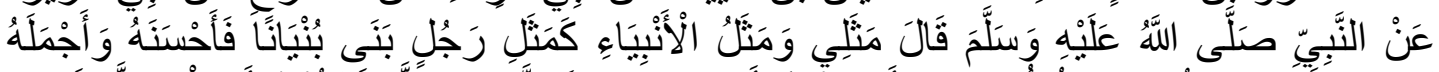

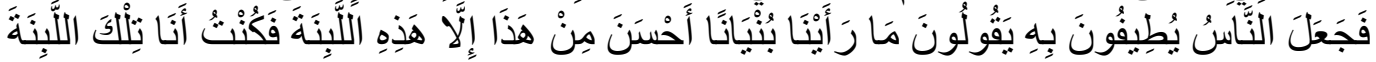

Artinya: Telah menceritakan kepada kami Amru bin Muhammad An Naaqid Telah menceritakan kepada kami Sufyan bin Uyainah dari Abu Zinad dari Al A'raj dari Abu Hurairah dari Nabi shallallahu 'alaihi wasallam sabdanya: "Perumpamaanku dengan Nabi-nabi sebelumku adalah seperti orang membangun sebuah bangunan, lalu dia sempurnakan dan diperbagus bangunannya, hingga orangorang pun mulai mengelilingi bangunan tersebut seraya berkata; 'Aku tidak melihat bangunan yang lebih bagus dari ini. kecuali sebuah sudut (belum terpasang) dengan sebuah bata. Maka akulah yang meletakkan atau memasang bata itu." (H.R. Muslim No. 4237). ${ }^{14}$

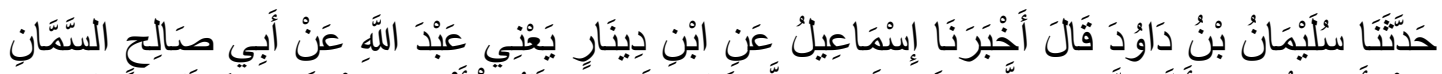

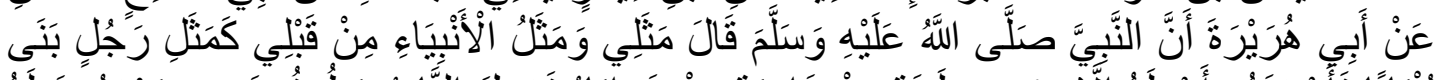

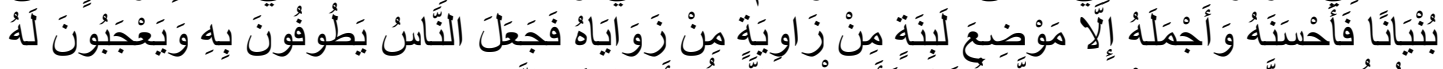

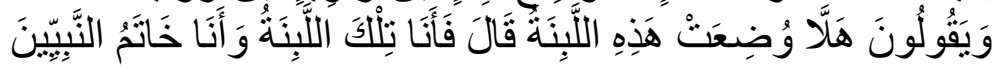

Artinya: Telah menceritakan kepada kami Sulaiman bin Dawud berkata; telah mengabarkan kepada kami Isma'il dari Ibnu Dinar -yaitu Abdullah- dari Abu Shalih As Samman dari Abu Hurairah,

${ }^{13}$ H.R. Bukhari, Hadits Sembilan No. 3271.

${ }^{14}$ H.R. Muslim, Hadits Sembilan No. 4237. 
bahwasanya Nabi shallallahu 'alaihi wasallam bersabda: "Permisalanku dengan para Nabi sebelumku adalah seperti seorang laki-laki yang membuat bangunan, ia memperbagus dan memperindahnya kecuali satu bata pada salah satu sudut bangunan tersebut, maka manusia berkeliling dan merasa kagum, dan mereka berkata; 'Sekiranya satu bata ini disempurnakan, ' beliau bersabda: "Maka aku adalah satu bata tersebut, dan aku adalah penutup para Nabi."( H.R Ahmad No.8802). ${ }^{15}$

أخبرنا عبد الله بن عبد الحكم المصري حدثنا بكر بن مضر عن جعفر بن ربيعة عن صالح هو

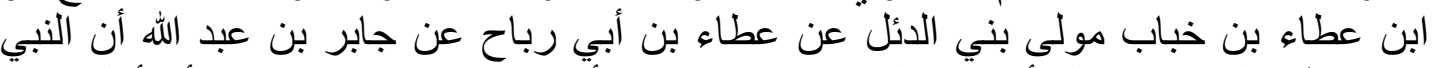

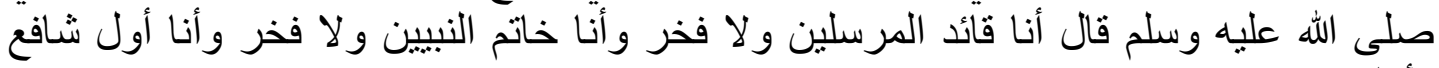
و أول مشفع و لا فخر

Artinya: Telah mengabarkan kepada kami Abdullah bin Abdul Hakam Al Mishri telah menceritakan kepada kami Bakar bin Mudlar dari Ja'far bin Rabi'ah dari Shalih Ibnu 'Atha' bin Khabbab bekas budak dari bani Al Duil dari 'Atha' bin Abi Rabbah dari Jabir bin Abdullah Radliyallahu'anhu Bahwasannya Nabi shallallahu 'alaihi wasallam. bersabda: "Saya adalah pemimpin para Rasul, dan tidak ada kesombongan, saya adalah penutup para Nabi dan tidak ada kesombongan, saya adalah orang pertama yang akan memberi syafa'at dan orang pertama yang diberi syafa'at dan tidak ada kesombongan".( H.R. Darimi No.49). ${ }^{16}$

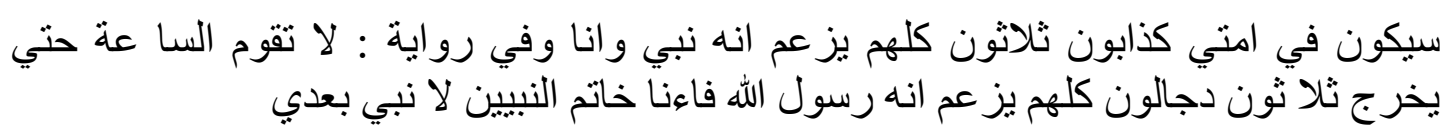

Artinya:... akan ada ditengah ummatku 30 orang pendusta semuanya menganggap dirinya adalah nabi Allah dan aku (Muhammad Saw) adalah penutup para nabi dan tida ada lagi nabi selain itu. Dalam riwayat lain: tidak akan terjadi hari kiamat sehingga muncul 30 dajjal, semuanya menganggap dirinya rasul Allah, maka aku adalah penutup para nabi dan tidak ada lagi nabi sesudahku. ${ }^{17}$

${ }^{15}$ H.R. Ahmad, Hadits Sembilan No. 8802.

${ }^{16}$ H.R. Darimi Hadits Sembilan No. 49.

${ }^{17}$ H.R. Abu Daud No. 2347/Nyonya Hadiah Salim Mukhtarul Ahadits (Bandung: Diponegoro, 1989), hlm 76. 


\section{Wacana Bagi yang Memandang Masih Ada Nabi Sesudah Nabi Muhammad SAW}

a. Hadits 1

$$
\text { تلا تقوم الساعة حتي يملك الناس من اهل بيتي يو اطيء اسمه اسمي واسم ابيه اسم ابي فيهلوهها }
$$

Artinya: ...."kiamat tidak akan terjadi sampai semua manusia dipimpin oleh seorang lelaki dari ahlul bait. Dia akan memunculkan diri dengan sendirinya. ${ }^{18}$

b. Hadits 2

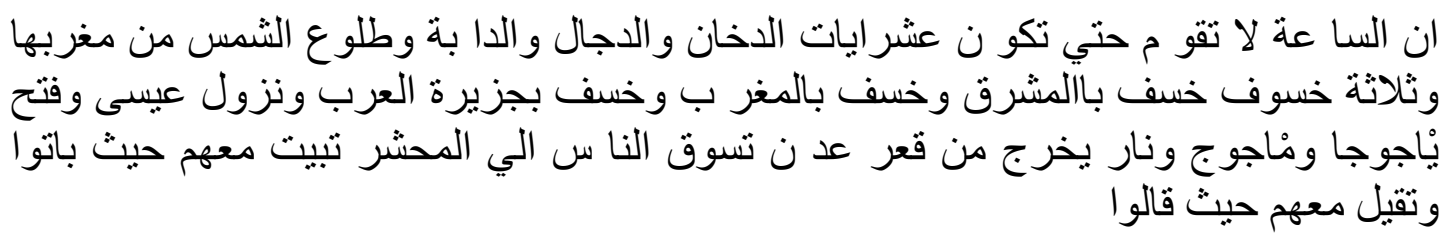

Artinya: Sesungguhnya kiamat itu tidak akan terjadi kecuali setelah ada sepuluh tanda: gelap, dajjal, debah, terbit matahari disebalah barat, terjadi tiga gerhana, gerhana di sebelah timur, gerhana di sebelah baarat, gerhana di jazirah arab, turunnya nabi isya, ya'juj dan ma'juj, api keluar dari lembah and yang menggiring manusia ke padang mahsyar. Api itu tetap bersama mereka disaat mereka tidur malam dan siang dimanapun mereka berbicaraa. ${ }^{19}$ (H.R. Ahmad, Muslim dan Ashab Sunan dari Huzaifah Bin Usaid).

c. Hadits 3

عن عاءشة رضي الله عنها قالت قال رسول الله صلي الله عليه وسلم قولوا خاتم النبيين

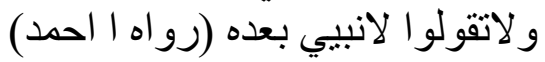

Artinya: dari aisyah ra berkata rasullah saw bersabda: katakanlah penutup para nabi dan jangan kalian katakana tidak ada nabi sesudahnya. (Hadits ruayat ahmad). ${ }^{20}$

d. Hadits 4 Rasullah saw bersabda kepada Abbas:

فيكم النبوة و المملكة الخلافة فيكم و النبوة

${ }^{18}$ H.R. Tarmizi No. 2231.

${ }^{19}$ Ibn Hamzah Al-Husaini Al-Hanapi Ad-Damsyiqi, Asbabul Wurud Latar Belakang Hisroris Timbulnya Hadits-Hadits Rasul, Terjemah M. Swarta dan Zafaullah Salim, Jilid 1 (Jakarta: Kalam Mulia, 2003), hlm. 444.

${ }^{20}$ Al-qaul al- Shahih Diambil Dari Tafsir Ad-Dur Al-Ma'tsur Al Syuyuti. Lihat juga: Ihsan Ilahi Dzakir, Op.Cit., hlm. 239. 
Artinya: "... Ditengah-tengah kalian ada kenabian dan kerajaan khilafah di tengah kalian dan kenabian...." 21

e. Hadits 5 Rasullah saw. bersabda:

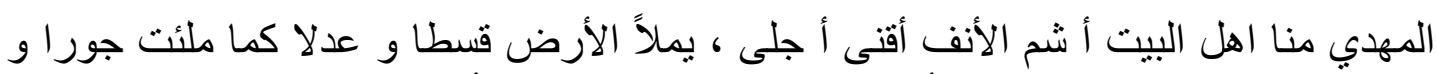

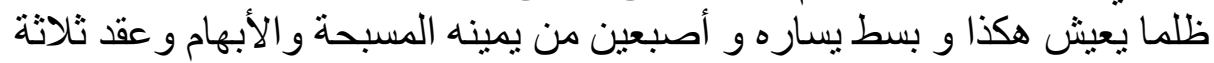

Artinya: Al-Mahdi dari kalangan ahlul baitku, dia berhidung mancung dan berdahi tebal, dia akan memenuhi bumi dengan keadaan sebagaiman sebelum telah dipenuhi dengan perilaku durjana dan kezhaliman. Dia akan berkuasa sebelum tujuh tahun. ${ }^{22}$

f. Hadits 6

عن ابي هريرة قال كنا جلوسا عندا النبي صلعم فاعنزلت عليه سورة الجمعة (واخرين منهم لما

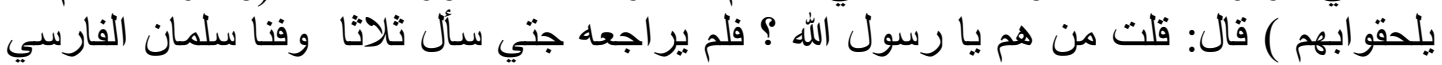

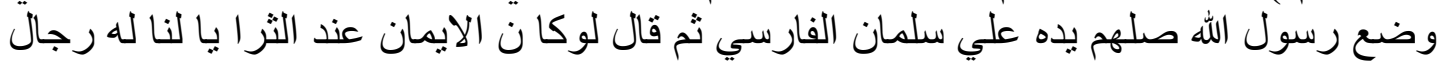

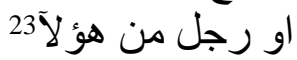

Artinya: Dari Abu hurairah r.a. Pada suatu hari kami duduk duduk beserta Rasululah SAW. Lalu diturunkan kepada beliau surah al Jumu'ah, pada kata kata (Dan Dia akan membangkitkannya pada kaum lain dari antaramereka yang belum pernah bertemu dengan mereka), Saya bertanya siapa yang dimaksud dengan mereka ya Rasulallah? Beliau tidak menjawab hingga saya menanyakan itu sampai tiga kali.Diantara kami ada duduk Salman al Faris (Salman Berbangsa Persia) dan Rasulullah Saw. Meletakkan tanga $\mathrm{n}$ beliau di atas pundak Salman ,lalu bersabda: Bila iman telah terbang ke bintang Tsuroya seorang lelaki atau beberapa orang dari antara mereka ini (yang akan mengambilnya kembali). ${ }^{24}$

\section{Asbabun Nuzul dan Asbabul Wurud}

Alangkah eloknya kajian hadits tematik tentang kenabian diawali dengan ayat Alquran sebagai dasar pertama dan utama disarahkan oleh matan matan hadits Rasulullah Saw. Sehingga madlulnya lebih dipahami sebagai bayan lilayah.

\footnotetext{
${ }^{21} \mathrm{Ibid}, \mathrm{hlm} .241$.
}

${ }^{22}$ H. R. A. Hakim. No. 8670, Imam Ibn Qoyyim Fi Al Manar Al Munif, mengatakan bahwa: Diriwayatkan oleh Abu Daud dengan Sanad Yang Hasan.

${ }^{23}$ Asrar Makrur Paja, Membela Diri Dengan Hadits Nabi Bagi Ahmadiyah, Makalah Seminar Nasional, 27-10-2018 Di Aula Dakwah Uinsu Medan.

${ }^{24} \mathrm{PBJ}$. Ahmadiyah Indonesia, Kami Orang Islam...hlm.70. 
Dengan demikian, ayat yang eksplisit tentang kenabian termasuklah Quran Surah al-Ahzab ayat: 40 saja, akan tetapi sebagai suatu wacana ayat ayat berikut merupakan perhelatan yang juga mewarnai dan turut menjadi rujukan yaitu antara lain: Q.S al Nisa: 60, Q.S al-Hajj: 75, Q.S.al Nisa: 164, Q.S.al Mukmin:78 dan Q.S.al A'raf: 35 meskipun sebenarnya ada yang menjadi perbedaan karena dipandang sebagian besar hanya silat lidah yang berpotensi mengada ada dan penafsiran parsial tidak komprehensif sesuai kaidah.

Justru dalam pasal ini penulis hanya mencantumkan sebab turun salah satu ayat yang menurut penulis lebih muktabar dan valid yaitu Q.S al-Ahzab: 40 dimaksud dengan penjelasan sebagai berikut:

Ketika Rasulullah saw. bertemu dengan Zainab binti Jahsy banyak memperbincangkan bahwa Muhammad mengawini mantan istri anaknya maka turunlah ayat 40 Suroh al-Ahzab yang menjelaskan bahwa dia (Muhammad saw.) bukan bapak dari Zaid dan Zaid bukan putra dari nabi Muhammad, akan tetapi biliau adalah Rasul Allah dan penutup para nabi. ${ }^{25}$ Adapun ayat yang lain yang dipaparkan di atas tidak lagi penulis cantumkan kajian kajiannya karena dipandang ayat eksplisit yang langsung secara gamblang mewakili yang berbentuk inplisit, artinya yang tersurat didahulukan dari yang tersirat, itulah Q.S.al Ahzab ayat 40.

Adapun hadits yang pertama, bagi yang memandang masih adanya kenabian setelah nabi Muhammad SAW. adalah hadits dari Rasullulah SAW. bukan sekedar issu yang menjelaskan tanda-tanda akhir zaman akan ada seorang pemimpin yang berasal dari ahli bait Rasul yang namanya persis dengan biliau. Sebab muncul hadits ini saat sekelompok sahabat bermujadalah tentang kiamat, ada yang lain menggambarkan hal ihwal menjelang kiamat itulah yang lebih kacau. Ternyata kacau yang di maksud bukan saja kekacauan alam fisik yang porak poranda,tetapi juga porak poranda akibat ketidak adilan pemegang kewenangan, bisa saja pemerintah dan orang pengambil kebijakan

Hadits kedua juga dijelaskan dalam kitab asbabul wurud bahwa: diriwayatkan di dalam shohih muslim dari Huzaifah bahwa Rasullah saw berada di kamarnya sementara para sahabat sedang berbincang-bincang, tiba-tiba Rasullah datang bertanya: apa yang sedang kalian bicarakan?, mereka menjawab: hari kiamat, kemudian Rasullah bersabda sebagaimana bunyi hadits nomor dua termaktub sebelumnya. ${ }^{26}$

\footnotetext{
${ }^{25}$ H. A. A. Dahlan dan M. Zaki Alfarisi, Asbabun Nuzul (Bandung: Civi. Diponegoro, 2007), hlm. 433.

${ }^{26}$ Ibn Hamzah Al Husnaini Al Hanapi Al Dimsaki, Op.Cit., hlm. 445.
} 
Kemudian hadits tiga, empat, dan lima dipandang sebagai statement nabi saja tanpa ada sebab wurudnya. Berbeda dengan hadits ke enam sebagai bahan bahwa negeri Persia tempat asal keluarga Salman al Faris yang dalam silsilah keturunan putri Rasul “Fatimah " sampai ke generasi setelahnya ada menikah dengan bangsa Persia dan dari Salman telah muncul laki-laki yang patut mendekati nabi.

Di sisi lain, hadits nomor enam itu menunjukkan kriteria imam mahdi yang ditungu-tunggu syi'ah secara umum, baik Syiah aliran Isna Asyar dan aliran lainnya Ahmadiyah Qodianiyah berkeyakinan juga akan lahir tapi disembunyikan hanya beberapa yang fahamlah yang mengetahuinya. Kehadirannya diakhir zaman berasal dari keturunan Salman al Farisi dari Persia, menjadi pigur dan panutan contohan dia keturunan Fatimah binti Rasul, manakala diusut terus ke belakang dia tidak lain adalah Mirza Ghulan Ahmad yang selalu menjadi perdebatan dan pembicaraan. Untuk menepis hal tersebut hadits nomor enam menjadi jawaban antara penantian dan pencarian.

\section{Kritik Sanad dan Matan Hadits}

Hadits-hadits yang di kedepankan pada wacana penolakan adanya nabi setelah Rasullah saw, pada dasarnya mutawatir dan jelas makna dan kalimatnya.

$$
\text { انا خا تم النبيين لا نبي بعدي }
$$

Artinya: "... Saya adalah penutup para nabi, tidak ada nabi sesudahku...,27

Kalimat potongan "... Ana khatamun Nabiyyin La Nabiya Ba'diy..." yang ada pada hadits 1, 3, 4, dan 5 di atas, merupakan hadits yang derajatnya ada yang sahih dan hasan lizatih dilihat dari rentetan orang orang yang menjadi sumber berita (sanad) sampai kepada Rasul yakni hadits ittishal.

Kemudian difahamkan bahwa hadits-hadits yang memberi ruang kemungkinan adanya nabi setelah Rasulullah Saw. sebagaimana dicantumkan dalam pasal ini, baik sanad ${ }^{28}$ maupun matannya ${ }^{29}$ di dipandang bermasalah.dan berikut ini langkah-langkah untuk mengkritisinya, sebagai berikut:

${ }^{27} \mathrm{Abu}$ Daud Sulaiman Bin Al Asy'at, Sunan Abi Daud (Riat: Bait Al Aktar al Damiyah, t.t.), hlm. 469.

${ }^{28}$ Sanad adalah silsilah orang-orang yang meriwayakan hadis yang menyampaikannya kepada matan hadis. Lihat: Munzir Suparta, Ilmu Hadits (Jakarta: PT. Raja Grapindo Persada, 2002), hlm. 45.

${ }^{29} \mathrm{Ibid} .$, hlm. 49. 
1. Hadits 1 H.R. Attirmizi No. 2231

Menurut perawi hadits imam Turmuzi bahwa hadits no. 2231 yang merupakan dalil bahwa akan ada dari ahlul bait lahir atau muncul seorang yang akan memimpin semua manusia. Kualitas hadits tersebut adalah Shahih lizatih, bila perlu ditopang dengan adanya juga pada riwayat imam Ahmad No. 3571 dari Ibnu Abi Syaibah dan Ibnu Hibban No. 5954, 6825, Imam Thabarani dalam Mu'jam al Kabir No.10219, Abu Nuaim al Asbhani, al Khatib al Baghdadi melihatnya hadits shahih lizatih.

2. Adapun hadits nomor 2 (H.R.Ahmad dan Muslim)

3. Tiga, empat dan lima sanadnya tidak tercantumkan sebagai salah satu cacat dalam kritik hadits. Apatah lagi mengkaji dan menelusuri orang-perorang dalam tabaqat ${ }^{30}$ sanad merupakan

\section{Pengkajian tentang Teks Hadits}

Hadits-hadits yang di kedepankan pada wacana penolakan adanya nabi setelah Rasullah saw, pada dasarnya mutawatir dan sharih alias jelas makna dan kalimatnya.

$$
\text { انا خا تم النبيين لا نبي بعدي }
$$

Artinya: "... Saya adalah penutup para nabi, tidak ada nabi sesudahku..."31

Kalimat potongan “... Ana khatamun Nabiyyin La Nabiya Ba'diy...” yang ada pada hadits $1,3,4$, dan 5 di atas, merupakan hadits yang derajatnya sahih dan hasan lizatih, dalam arti kata tidak diragukan sanad maupun matannya,bahkan haditsnya banyak dan didapati hampir disemua perawi hadits.

Kata "Khatam" yang ada di dalam ayat Alquran (Q.S. al Ahzab: 40) maupun yang ada di dalam hadits hadits sebagaimana termaktub sebelumnya, merupakan titik awal dari perhelatan dan kajian tentang ada tidaknya nabi setelah Muhammad SAW. Dalam tulisan ini diutarakan dua aliran yang getol membicarakannya dan satu menanggapi.

1. Syiah

a. Dengan Dalil Hadits No.1

Artinya: ..."kiamat tidak akan terjadi sampai semua manusia dipimpin oleh seorang lelaki dari ahlul bait. Dia akan memunculkan diri dengan sendirinya”.

\footnotetext{
${ }^{30}$ Kritik Ini Termasuk Dalam Bahasanya, Bukan saja Disanad atau Matan. Lihat: Muhammad Mustafa Azani, Metodologi Kritik Hadis (Jakarta: Pustaka Hidayah, 1992), hlm. 81-82.

${ }^{31} \mathrm{Abu}$ Daud Sulaiman Bin Al Asy’at, Sunan Abi Daud...hlm. 469.
} 
Tidak akan terjadi kiamat kalau belum semua manusia dipimpin oleh Ahlulbait yang muncul dengan sendirinya. Hal ini menurut mereka adalah imam Mahdi yang manakala diusut sampai ke atas dia berasal dari regenerasi Fatimah binti Rasul yang muncul dari Persia sebagaimana dalam hadits ke enam, yang dikiaskan oleh Rasul bilamana iman manusia kiranya telah terbang ke bintang Tsaroya, yang mampu menjemput dan mengembalikannya adalah orang yang berasal dari Salman al Farisi, inilah nabi yang ditunggu itu.

b. Hadits ke 3:

Artinya: dari aisyah ra berkata rasullah saw bersabda: katakanlah penutup para nabi dan jangan kalian katakan tidak ada nabi sesudahnya. (Hadits riwayat Ahmad).

Bagi Syiah hadits dimaksud di atas merupakan angin segar yang mafhum mukhalafahnya masih ada nabi setelah nabi Muhammad SAW. Jangan katakan tidak ada nabi sesudahnya!, lalu bagaimana? Tentu sebaliknya ada.

c. Hadits ke 4:

Artinya: "... Ditengah-tengah kalian ada kenabian dan kerajaan khilafah di tengah kalian dan kenabian...."

Kenabian tetap hidup tidak pernah mati yang terus dipropagandakan untuk dipahamkan dan diyakinkan orang yang kemampuannya bisa membangun kerajaan dan kepemimpinan. Dari teksnya tampak diulang dua kali tentu memiliki makna penguatan. Demikian juga dipahami dari hadits seperti berikut ini:

$$
\text { ان الله عزوجل يبعث لهذه الامة على رأس كل ما ئة سنة من بجدد لها دينها }
$$

Artinya: "Sesungguhnya Allah yang maha gagah akan mengutus didalam ummat ini ( mujaddid) pada setiap permulaan seperti tahunan seorang reformasi yang memperbahrui agamanya", dengan kesimpulan tetap terbuka demi pembaharuan".

2. Ahmadiyah Qodiyaniah

Menurut beberapa literature sekte ini selalu mengeluelukan Mirza Ghulam Ahmad yang dipandang manusia super bahkan keberadaannya makhfiyan tersembunyi bahkan tidak banyak orang tau meskipun tetap memiliki sifat sifat anatomi dan sifat fsikis yang bisa di amati atau diobservasi. Dalam uraian ini berdalilkan:

Hadits No. 5

Artinya: Al-Mahdi dari kalangan ahlul baitku, dia berhidung mancung dan berdahi tebal, dia akan memenuhi bumi dengan keadaan 
sebagaiman sebelum telah dipenuhi dengan perilaku durjana dan kezhaliman. Dia akan berkuasa sebelum tujuh tahun.

Hadits ini merupakan konsdran akan munculnya al Mahdi, tetapi al Mahdi itu juga bernama Isa yang bisa juga bernama lain seperti MirzaGhulam Ahmad yang akan memperbaiki kezaliman menjadi kesalehan penuh keadilan dan cinta kasih kepada segenap umat. Bagi sekte ini Atsar dapat sebagai sumber hukum, tepatnya sebagaimana perkataan berupa statemen Ali Karramallahu Wajhahu:

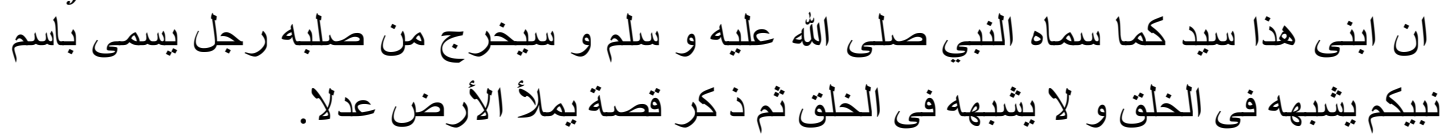

Artinya: Puteraku ini akan menjadi orang besar sebagaimana disebutkan oleh nabi Muhammad SAW. dan akan keluar dari sumsumnya seorang lelaki bernama sama dengan nabi kalian, akhlaknya sama dengan akhlak nabi kalian tetapi tidak dengan perawakannya, Lantas dia menyebutkan satu kisah dan berkata "Dia akan memenuhi bumi dengan keadilan".

Atsar ini menurut Ibnu Katsir al Dimsyaqy yang dimaksudkan adalah imam al Mahdi dari kalangan ahlul bait,keturunan Fatimah binti Rasul dari keturunan Hasan bin Ali sendiri. ${ }^{32}$

3. Ahlu Sunnah Wa al Jama'ah

Kelompok Ahlu sunnah wa al Jamaah yang memandang tidak ada lagi nabi setelah nabi Muhammad SAW. berargumentasi:

a. Masalah kenabian telah di pandang final dan berada pada qathai dilalah, mutlak dan tak tergugat, baik dari segi sanad-sanad hadits, matan yang diperoleh para perawi tidak ada yang menjatuhkan pendapat secara eksplisit, meskipun dalam perbuatan pihak yang mengganggap kenabian tetap ada, dimana alasan-alasan dicari dari berbagai segi.

Di dalam Q.S. al Ahzab ayat 40 sebagaimana termaktub sebelumnya telah dinyatakan oleh Allah SWT. bahwa Muhammad SAW. adalah rasul-Nya dan khatam al Nabiyyin, kata khatam di ayat dimaksud memakai isim fail yang kebetulan di nasabkan dengan tanda al Fath. Apa maknanya dengan memakai wazan isim fail? Jawabannya sesuai artinya "nama pelaku" yakni oknum yang menyandang predikat nabi itu benar benar manusia atau orang,

${ }^{32}$ Ibnu Katsir, Al Nidhyah Fi al Fitan Wa al Malahim ( Beirut : Daar al Fikr,t.t),hlm. 61 
itulah dia Muhammad SAW. tidak ada yang lain. Ini makna yang terkandung di dalam pola kalimat dengan wazan fail.

b. Meskipun kata khatamun sebagai isim musytarak yang memiliki makna ganda, stempel,materai,lak,penutup dan cincin yang dipahamkan bahwa kenabian bagaikan cincin yang tak ada ujung dan pangkalnya, namun bagi kelompok ini telah final karena hadits tidak akan bertentangan dengan Alquran,bahkan dalam ulumul Quran, usul fiqh dan ulumul hadits (Mushthalah al Hadits dan .) hadits sebagaibayan lil ayah.

c. Adapun kalimat yang dipandang hadits yang menyatakan ada lagi nabi setelah nabi MuhammadSAW. Semuanya harus dipahami sebagai ma'nawy bukan makna hakiky. Argumentasi Syiah yang sering mengedepankan al Mahdi harus dimaknai secara maknawiah, artinya secara tematik lihatlah apa asal kata almahdy itu? Jawabannya tentu Hudan berubah ucapan menjadi mahdiyun atau al Mahdi sebagai isim zaman dan isim makan.

Lalu apa hudan itu? Jawabannya adalah petunjuk, petunjuk itu apa pula ? Jawabannya adalah "Alquran”, sesuai dengan jawaban seorang janazah saat ditanyai malaikat munkar dan Nakir"di alam barzah : Ma Imamuka? Dia akan mampu menjawab Alquranu imamy (Apa ikutan/imammu? Ikutan/imamku adalah Alquran.

Jadi al Mahdy yang disifati bijak, adil dan membawa ketenteraman adalah Alquran, yang dapat hidup sepanjang zaman dan memasuki seluruh tempat, orangnya bisa dari mana saja apabila ia mengamalkan isi kandungan Alquran dengan sebaik baiknya dan sebenar benarnya.

Ketika seseorang telah mengamalkan isi kandungan Alquran dengan baik dan benar, maka jadilah dia orang yang adil dan membawa kedamaian dan keselamatan untuk lingkungannya. Untuk skop yang lebih luas, alam semesta tentu bukan sekedar orang biasa,mungkin peminpin dan sekaligus penguasa yang mengikuti kelas nabi. Adanya nama khusus seperti Isa, Mirza Ghulam Ahmad atau al Mahdi tidak menjadi soal, karena hakikatnya adalah pengaplikasian Alquran, dia bisa disebut nabi ( Pemberi khabar berita), tetapi dia tetap tidak bisa melebihi Muhammad SAW. karena beliaulah pemungkas tidak ada pemungkas sesudahnya lagi membawa rahmat bagi seluruh alam.

Tentang ayat ini dikuatkan oleh ayat lain sepserti Q.S. al Anbiya:107

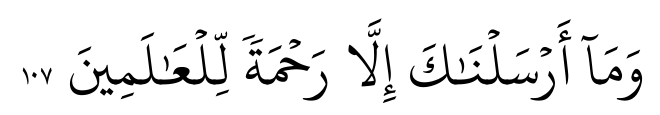

Artinya: Dan Tiadalah Kami mengutus kamu, melainkan untuk (menjadi) rahmat bagi semesta alam. 
Mujaddid sebagai pembaru yang dapat bersifat adil, membimbing umat dengan etis, berperadaban dan berkemajuan sehingga terasa dan terukur sebagai rahmat bagi seluruhnya bisa saja ulama yang dikatakan sebagai pewaris nabi yang dimintakan dan dirindukan umat untuk menjadi leader dan manager di segala bidang. Khatam yang diartikan cincin melingkar tidak ada ujung dan pangkal, seperti itu juga di imankan tentang ke nabian yakni tidak ada ujungnya yakni masih tetap terbuka dan bisa jadi ada, dia tidak nabi, hanya sejajar dengan para ulama,cendikiawan, ululalbab yang berpadu dalam dirinya berbagai kompetensi dan keunggulan.

\section{Kesimpulan}

Masalah kenabian merupakan diskusi yang dalam tulisan ini ada tiga sekte yang ambil bagian membicarakannya yaitu Syiah, Ahmadiyah Qodianiyah dan Ahlu Sunnah wa al Jama'ah dengan melahirkan tiga kesimpulan yaitu : pertama, Kenabian dapat dipandang sesuatu yang telah final dan mereka merasa mubazir untuk membicarakannya apalagi berimplikasi sia-sia. Kedua, Kenabian tetap ada dan terbuka berdasarkan hadits dan atsar. Ketiga, ada integritas dimana penafsiran dari sekte sekte yang berhelat dipadu sehingga lahir pemikiran dengan pemahaman baru sebagai kajian bidang ke filsafatan. Tidak ada yang mustahil untuk dibahas bahkan eksistensi Allah Swt masih di diskusikan oleh para filosof ternama termasuk para calon pemikir di AFI UINSU Medan.

Kenabian tetap ada sejak nabi masih hidup, seperti Musailimatul Kazzab apalagi dalam aliran syiah dengan istilah Imam Mahdi dan pada aliran Ahmadiyah Qadianiyah dengan nama Mirza Ghulam Ahmad, bahkan Muktazilah masih ikut serta membicarakan hal-hal kenabian ini.

Level lokal seperti di Indonesia ada sepuluh orang yang mendeklarasikan diri sebagai nabi yaitu Abdul Muhjid, Sri Hartati, Starmin, Eyang Ended, Hadasari, Musjari, Cecep Sholihin, Asrianti Samuda, Lia Eden dan Ahmad Musaddeq. ${ }^{33}$

${ }^{33}$ Iyakan. Com, Diakses pada hari rabu, 12 desember 2018 pukul 08.45. 


\section{Referensi}

Abu Abdillah Muammad Bin Ismail Al-Bukhari, Shahih Bukhari, cet.1, Beirut: Dari Ibn Katsir, 2002.

Abu Daud Sulaiman Bin Al Asy'at, Sunan Abi Daud, Riat: Bait Al Aktar al Damiyah, t.t.

Ahmad Warson Munawwir,Al Munawwir Kamus Arab-Indonesia, Yogyakarta: Pustaka Progressif, t.t.

Asrar Makrur Paja, Membela Diri Dengan Hadits Nabi Bagi Ahmadiyah, Makalah Seminar Nasional, 27-10-2018 Di Aula Dakwah Uinsu Medan.

Depag. RI. Al Quran dan Terjemahnya, Semarang: Toha Putra 1998.

H. A. A. Dahlan dan M. Zaki Alfarisi, Asbabun Nuzul, Bandung: Civi. Diponegoro, 2007.

Ibn Hamzah Al-Husaini Al-Hanapi Ad-Damsyiqi, Asbabul Wurud Latar Belakang Hisroris Timbulnya Hadits-Hadits Rasul, Terjemah M. Swarta dan Zafaullah Salim, Jilid 1, Jakarta: Kalam Mulia, 2003.

Ibnu Katsir, Al Nidhyah Fi al Fitan Wa al Malahim, Beirut: Daar al Fikr, t.t.

Ihsan Ilahi Dzakir, Ahmadiyah Qadiyahmiah, Sebuah Kajian Analisis, Terjemah Harapaudi Dahri Jakarta: BPPA, 2008.

Mohammad Daud Ali, Pendidikan Agama Islam, Jakarta: Raja Grafindo Persada, 1998.

Muhammad Mustafa Azani, Metodologi Kritik Hadis, Jakarta: Pustaka Hidayah, 1992.

Munzir Suparta, Ilmu Hadits, Jakarta: PT. Raja Grapindo Persada, 2002.

Nyonya Hadiah Salim Mukhtarul Ahadits, Bandung: Diponegoro, 1989. 